\title{
Anaplastic lymphoma kinase (ALK) inhibitors for second-line therapy of non-small cell lung cancer
}

\author{
This article was published in the following Dove Press journal: \\ Lung Cancer:Targets and Therapy \\ 17 December 2012 \\ Number of times this article has been viewed
}

\section{Thierry Berghmans' \\ Myriam Remmelink ${ }^{2}$ \\ Ahmad Awada $^{3}$}

'Clinic of Thoracic Oncology and Department of Intensive Care, Institut Jules Bordet, Université Libre de Bruxelles, Brussels, Belgium; ${ }^{2}$ Department of Pathology, Hôpital Erasme, Université Libre de Bruxelles, Brussels, Belgium; ${ }^{3}$ Medical Oncology Clinic, Institut Jules Bordet, Université Libre de Bruxelles, Brussels, Belgium

Correspondence:Thierry Berghmans Institut Jules Bordet, I Rue HégerBordet, Brussels BI000, Belgium

Tel +32 $254|319|$

Email thierry.berghmans@bordet.be

\begin{abstract}
Targeted therapies are nowadays a treatment option in metastatic non-small cell lung cancer, for which oncogenic drivers have been identified. The epidermal growth factor-receptor tyrosine kinase inhibitors gefitinib and erlotinib, are the standard of care for patients in whom tumors are presenting with an activating epidermal growth factor-receptor mutation, with new active agents like afatinib reaching clinics in the near future. Other genetic abnormalities have been documented in squamous and non-squamous lung cancer. The EML4-ALK gene fusion is a rare event, occurring in around $5 \%$ of lung cancer, quite exclusively in adenocarcinoma with a predominance of young non/light smokers. Detection of $A L K$-positive tumors is challenging, as there is no gold-standard technique. Fluorescence in situ hybridization is the method used in prospective trials assessing the activity of crizotinib and is recommended by the American FDA. Crizotinib is the first orally active inhibitor of receptor tyrosine kinases, including $A L K$ and ROS1, in clinical practice. Impressive results came from a phase I study and are now confirmed in a large phase II study with response rate of $60 \%$, whatever the number of previous lines of chemotherapy. Other $A L K$ inhibitors are currently in the preclinical phase, and some are showing promising results in early phase I/II studies. This review aims to present the current knowledge on the $E M L 4-A L K$ gene fusion, the pitfalls for the pathologist and the clinician in searching this abnormality, and to review the existing literature on $A L K$ inhibitors under development, focusing their role compared to chemotherapy in non-small cell lung cancer patients.
\end{abstract}

Keywords: non-small cell lung cancer, $E M L 4-A L K$, crizotinib

\section{Introduction}

Lung cancer, the leading cause of cancer death worldwide, has long been considered for therapeutic purposes as composed of two distinct entities, small and non-small cell lung carcinoma (NSCLC), the latter accounting for $85 \%$ of the cases. At diagnosis, the majority of NSCLC present with locally advanced or metastatic disease,${ }^{1}$ for which only palliative chemotherapy can be proposed, while survival advantage has systematically been observed in comparison with supportive care. ${ }^{2}$ During the last few decades, improvements in chemotherapy administration and development of new cytotoxic agents have led to increased survival rates despite considerable acute and chronic toxicity from first-line platinum-based regimens. With time, more patients became eligible for salvage chemotherapy. The most common drugs given in second line for relapsed or progressing NSCLC are currently docetaxel and pemetrexed, while other drugs have shown some efficacy in a few studies. ${ }^{3}$

Over the last decade, better biology knowledge has led to differentiating NSCLC in subgroups with variable susceptibility to anticancer drugs. Histology was a first step, 
showing, for example, with pemetrexed a differential sensitivity to the drug in favor of nonsquamous NSCLC. ${ }^{4}$ Further studies demonstrated that genomic alterations are different when looking at squamous ${ }^{5}$ and nonsquamous histology. ${ }^{6}$ Currently, at least $50 \%$ of adenocarcinomas present with a known genomic abnormality or an oncogenic driver, the most frequent being $K R A S$ and $E G F R$ mutations. ${ }^{6}$ The latter now has clinical implications with the development of the highly active EGFR tyrosine kinase inhibitors gefitinib, erlotinib, and afatinib.

A few years ago, a new gene alteration was discovered from a surgically resected lung adenocarcinoma, ${ }^{8}$ the $E M L 4-$ $A L K$ fusion gene, leading rapidly to the fruitful search for a selective inhibitor that is now reaching the clinic. The aims of this article are to present the current knowledge on this fusion gene, the pitfalls for the pathologist and the clinician in searching for this abnormality, and to review the existing literature on $A L K$ inhibitors, focusing on their role in the therapeutic algorithm of NSCLC patients.

\section{The EML4-ALK fusion gene}

The anaplastic lymphoma kinase gene $(A L K)$ is located on chromosome $2 \mathrm{p} 23$. Its normal expression is restricted to the brain, testes, and small intestine, having similarity to the insulin-receptor subfamily of kinases. This gene was originally established for its implication in the pathogenesis of rare diseases, including inflammatory myofibroblastic tumors and $A L K$-positive anaplastic large-cell lymphomas. ${ }^{8}$ In 2007 , the fusion of $A L K$ with the echinoderm microtubule-associated protein-like 4 gene (EML4) was first identified in Japanese NSCLC. ${ }^{8}$ This gene fusion is due to small inversions on chromosome arm $2 \mathrm{p}$. Further publications underlined the importance of $A L K$ gene fusion in other cancers (breast, colon, esophagus), while point mutation or amplifications have been reported in neuroblastoma. ${ }^{9}$ Translocations in NSCLC are created between $A L K$ and a gene partner. EML4 is the main partner, ${ }^{9}$ but does not appear to be the exclusive one. Two other fusions have been described in NSCLC tumor samples, including $T R K$-fused gene ( $T F G$, located at $\left.3 \mathrm{q}^{12.2}\right)^{10}$ and the kinesin family member 5 gene (KIF5B, located at 10p11.22). ${ }^{11}$

At least eleven variants of the $E M L 4-A L K$ fusion gene (Figure 1) have been reported to date, all of which contain the same breakpoint in the $A L K$ gene but a different breakpoint in the EML4 gene. ${ }^{12,13}$ Most of them are oncogenic, as assayed in NIH-3T3 cells or in $\mathrm{Ba} / \mathrm{F} 3$ cells. The most common variants are E13, A20, and E6a/b; A20 is also referred to as variants 1 and $3 \mathrm{a} / \mathrm{b}$, which have been detected in $33 \%$ and $29 \%$

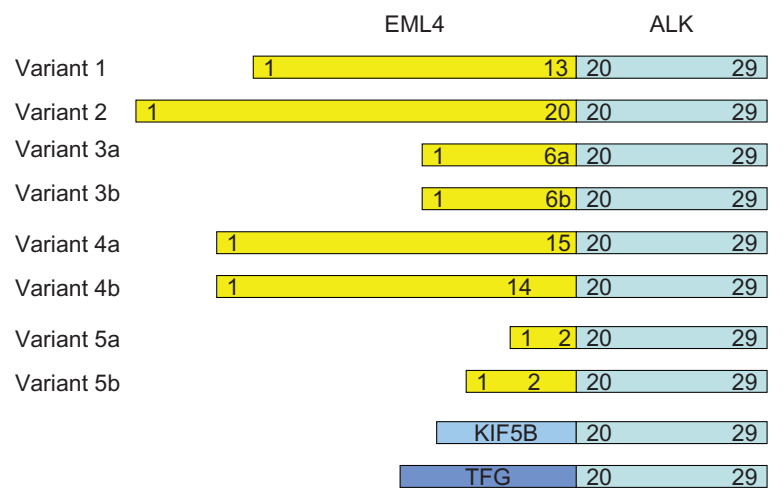

Figure I Graphic representation of the main variants of the $A L K$ fusion genes. Adapted from Atlas Genet Cytogenet Oncol Haematol. Perner S, Wilbertz T, StiedI AC, Rubin MA. EML4 (echinoderm microtubule associated protein like 4). Webpage on the internet available at http://atlasgeneticsoncology.org/Genes/EML4ID44353ch2p21.html. ${ }^{58}$

of NSCLC patients, respectively. ${ }^{6}$ The clinical significance, if any, of the different variants is currently not defined. Whatever considering a translocation or an inversion, the EML4-ALK gene fusion results in overexpression of the ALK protein, and subsequently overactivity of the ALK tyrosine kinase. ${ }^{8}$ This ALK protein tyrosine kinase is the target of inhibitors, of which crizonitib is the most advanced in clinical evaluation. ${ }^{12}$

At the difference of EGFR mutations, which are found in around $10 \%$ of adenocarcinoma in Caucasian patients, up to $30 \%-40 \%$ in East Asian ones, and virtually never in squamous histology, the $E M L 4-A L K$ fusion gene is generally observed in less than $5 \%$ of all NSCLC histological types, while some heterogeneity appears across the studies (Table 1). Histology is a main predictor of EML4-ALK positivity as it is essentially detected in adenocarcinoma (and adenosquamous carcinoma) and rarely in squamous cell carcinoma or in other histological subtypes (Table 1). Among adenocarcinomas, $A L K$-positive tumors have been detected in all histological subtypes, but especially in solid signet-ring cell and mucinous cribriform patterns. ${ }^{12}$ EML4-ALK-positive lung adenocarcinomas are significantly less differentiated and show significant associations with intra- and/or extracytoplasmic mucin, and cribriform pattern with excessive extracytoplasmic mucin. ${ }^{14}$ Other factors associated with the presence of the EML4-ALK fusion gene are younger age and smoking status, the abnormality being essentially found in non- or light smokers (Table 1). It was stressed early that $A L K$ rearrangement is mutually exclusive with such other mutations as $E G F R$ or $K R A S,{ }^{8,15-22}$ while recent evidence suggests that coexisting $A L K$ and $E G F R$ mutations can happen before any targeted treatment. The frequency observed in the European Erlotinib Versus Chemotherapy (EURTAC) trial, comprising only patients with activating EGFR mutations, was dependent on the technique of $A L K$ translocation 
Table I Summary of selected epidemiological studies assessing the frequency of the EML4-ALK fusion gene in NSCLC

\begin{tabular}{|c|c|c|c|c|c|c|}
\hline Reference & $\mathbf{n}$ & $\begin{array}{l}\text { EML4-ALK } \\
\mathrm{n}(\%)\end{array}$ & $\begin{array}{l}\text { ADC } \\
(n+/ n)\end{array}$ & $\begin{array}{l}\operatorname{SCC} \\
(n+/ n)\end{array}$ & Test & $\begin{array}{l}\text { Clinical characteristics associated } \\
\text { with } E M L 4-A L K\end{array}$ \\
\hline Soda et $\mathrm{al}^{8}$ & 65 & $5(7.7 \%)$ & 4 & I & PCR & - \\
\hline Koivunen et al ${ }^{17}$ & 305 & $8(2.6 \%)$ & $8 / 208(3.8 \%)$ & $0 / 88$ & FISH & Non/light smoking $(P=0.049)$ \\
\hline Inamura et $\mathrm{al}^{15}$ & 221 & $5(2.3 \%)$ & $5 / 149(3.4 \%)$ & $0 / 72$ & PCR & - \\
\hline Perner et al ${ }^{57}$ & 603 & $16(2.7 \%)$ & - & - & FISH & - \\
\hline Wong et $\mathrm{a}^{21}$ & 266 & $13(4.9 \%)$ & I I/209 (5.3\%) & $0 / 34$ & PCR & $\begin{array}{l}\text { Nonsmoking }(P=0.009) \text {, age } \\
(P=0.018)\end{array}$ \\
\hline Shaw et al ${ }^{18}$ & $14 \mid$ & $19(13.5 \%)$ & $18 / 130(13.8 \%)$ & $0 / 2$ & FISH & $\begin{array}{l}\text { Age }(P=0.005) \text {, male }(P=0.036) \text {, } \\
\text { non/light smoking }(P<0.00 \mathrm{I})\end{array}$ \\
\hline Inamura et al ${ }^{16}$ & 363 & II (3\%) & I I/253 (4.3\%) & $0 / 72$ & PCR & $\begin{array}{l}\text { Age }(P=0.006) \text {, light smoking } \\
(P=0.04) \text {, T status }(P=0.039) \\
\text { histological differentiation }(P=0.008)\end{array}$ \\
\hline Takahashi et a ${ }^{20}$ & 313 & $5(1.6 \%)$ & $5 / 211(2.4 \%)$ & $0 / 75$ & PCR & $\begin{array}{l}\text { Light smoking }(P<0.00 I) \text {, histological } \\
\text { differentiation }(P<0.00 I)\end{array}$ \\
\hline Sun et $\mathrm{al}^{19}$ & 52 & $3(5.8 \%)$ & $3 / 52(5.8 \%)$ & - & PCR & - \\
\hline Martelli et $\mathrm{al}^{29}$ & 120 & $9(7.5 \%)$ & $3 / 60(5 \%)$ & $4 / 48(8.3 \%)$ & PCR & - \\
\hline Zhang et $\mathrm{al}^{22}$ & 103 & $12(11.7 \%)$ & $10 / 62(16.1 \%)$ & $2 / 29(6.9 \%)$ & PCR & Nonsmoking $(P=0.03)$ \\
\hline Kwak et a $\left.\right|^{24}$ & 1500 & $82(5.5 \%)$ & 79 & I & FISH & - n n \\
\hline
\end{tabular}

Abbreviations: ADC, adenocarcinoma; FISH, fluorescence in situ hybridization; PCR, polymerase chain reaction; SCC, squamous cell carcinoma; $n+/ n$, number of patients with positive ALK testing between all tested patients.

assessment; up to $15 \%$ of 95 evaluated patients were positive for EML4-ALK by polymerase chain reaction (PCR), while only one of those 15 patients was positive by fluorescence in situ hybridization (FISH). ${ }^{23}$ This information, if confirmed, could have important clinical implications.

\section{The pitfalls in detecting the $A L K$ mutations}

As new therapeutics is currently available, it is critically important to select those patients who are more likely to have the $A L K$ gene abnormality. There is currently no gold-standard technique for detecting EML4-ALK in NSCLC. Several methods are available: FISH, reverse-transcriptase (RT)-PCR and immunohistochemistry (IHC).

$A L K$ positivity by FISH is used as an eligibility criterion in clinical trials with crizotinib. ${ }^{24}$ The presence of more than $15 \%$ tumor cells with an $A L K$ FISH-positive pattern using breakapart probes was the reference to prove the presence of an $A L K$ rearrangement in the patients enrolled in those studies. ${ }^{24,25} \mathrm{It}$ is the first FDA-approved method for detecting the $A L K$ fusion gene, ${ }^{26}$ and in the US, prescription of crizotinib is dependent upon the use of the Vysis ALK Break Apart FISH Probe Kit (Abbott Molecular, Des Plaines, IL, USA). Nevertheless, this technique has limitations for use in routine practice. The break-apart signal pattern resulting from the intrachromosomal deletion and inversion event in the setting of polysomy, typical of lung cancer, is subtle and easily missed. The morphologic features are lost with FISH analysis, which requires specialized equipment and highly trained readers for interpretation and remains time-consuming and costly. ${ }^{27}$

RT-PCR is a rapid diagnostic method and highly sensitive, as a very low RNA copy number is needed. The chromosomal inversion that characterizes the $A L K$ fusion makes the sequence unique, and the RT-PCR primer only hybridizes with the fusion chimeric transcript. This unique primer is responsible for the high sensitivity of this method. In order to target all the potential fusion variants that have been reported, RT-PCR has to be multiplexed, ie, several forward primers on EML4 ( \pm on other fusion partners) are required. Further, the diagnostic relevance of PCR directly relies on the quality of the extracted RNA, requiring a proper cryopreservation of tumor samples, and in this way is difficult to apply to archival tissues. ${ }^{26,28}$ These disadvantages make it unlikely that PCR will become the standard test for detecting the EML4-ALK fusion. ${ }^{12}$

IHC has the advantage of being a cheap, easy-to-use, and routine pathological technique. Theoretically, it has the ability to identify all $E M L 4-A L K$ variants, allowing a comparison with morphology, ${ }^{26}$ and is applicable on archival tissues. IHC positivity is dependent on the degree of expression of the EML4-ALK protein and commercially available $A L K$ antibodies have been reported to lack the sensitivity to detect the fusion protein. ${ }^{29}$ Agreement between the three detection methods is relatively poor and variable according to the EML4-ALK variant. ${ }^{13}$ A recent effort from the European Thoracic Oncology Platform allowed a better understanding of the role of IHC for $A L K$ translocation detection. From this consortium, 1099 stage I-IIIB 
NSCLCs were tested by IHC. Sixty-nine samples turned positive and were matched with 138 IHC-negative testing. From 60 IHC positive tumors (nine could not be tested by FISH), 22 were confirmed FISH-positive, while among 138 IHC-negative, only one was FISH-positive. The sensitivity and specificity of IHC were $37 \%$ and $90 \%$, respectively, but increased to $90.5 \%$ and $97.7 \%$ if only IHC $3+$ was considered. ${ }^{30}$ IHC could be viewed as a screening test with a high negative predictive value. If IHC is negative, the tissue is considered negative, but if it turns positive confirmation by another method is mandatory. ${ }^{12}$ This algorithm remains to be validated.

\section{ALK inhibitors for the treatment of NSCLC}

The first $A L K$ inhibitor, PF-02341066 or crizotinib, was developed by Pfizer (Table 2). It is an orally active inhibitor of receptor tyrosine kinases, including $A L K$ and mesenchymal epithelial growth factor (c-MET)/hepatocyte growth factor receptor $(H G F R) .{ }^{31}$ It blocks $A L K$ and $c-M E T / H G F R$ phosphorylation showing in vitro antiangiogenic and antimetastatic effects, inhibiting $A L K$-positive cell growth and inducing apoptosis of those cells. In vivo models in athymic mice showed reduction of $A L K$-positive or activated $c-M E T /$ $H G F R$ tumor xenografts. Crizotinib is metabolized by the cytochrome P450 3A4/5 (CYP3A) so that inducers or inhibitors of this enzymatic system can impact on drug exposure. A different pharmacologic profile has been reported between Asian and non-Asian patients.

\section{Phase I study with crizotinib}

Crizotinib demonstrated effectiveness during a doseescalation phase I study in two patients with NSCLC presenting with $A L K$ rearrangement. ${ }^{32}$ In an expanded cohort study, ${ }^{24}$ impressive response and 8 -week disease-control rates were observed of $57 \%$ (95\% confidence interval [CI] $46 \%-68 \%$ ) and $87 \%$, respectively. The results of this phase I study were recently updated. ${ }^{33}$ One hundred forty-three evaluable patients were included. The response rate (RR) was confirmed at $60.8 \%$ (95\% CI 52.3\%-68.9\%), with a median duration of 49.1 weeks (95\% CI 39.3-75.4 weeks). Most of the patients received crizotinib for salvage treatment after one $(32 \%)$, two $(21 \%)$, three $(13 \%)$, or more than three $(19 \%)$ previous chemotherapy lines. Nevertheless, results were similar whatever the number of previous treatments, with an RR of $63.6 \%$ in untreated patients and $59.1 \%, 64.5 \%$, and $58.7 \%$ for those having received one, two, or more than two previous chemotherapy treatments. Sensitivity (RR) to crizotinib appears independent of age $(<65$ years $60.2 \%$ versus $>65$ years 65\%), sex (male 64.8\% versus female $56.9 \%$ ), and performance status (Eastern Cooperative Oncology Group [ECOG] score 0, 54.7\% versus ECOG 1, 63.9\% versus ECOG 2, 66.7\%), while Asian patients seem more sensitive to the drug (RR 76.9\%, 95\% CI 60.7\%-88.9\%) than non-Asian ones (RR 54.8\%, 95\% CI 44.7\%-64.6\%). The estimated median progression-free survival was 9.7 months (95\% CI 7.7-12.8 months). At the time of analysis, median survival was not yet reached, and estimated 6- and 12-month survival rates were $87 \%$ and $74.8 \%$, respectively.

Table 2 Response rates reported in clinical trials testing ALK or Hsp90 inhibitors in ALK-positive NSCLC

\begin{tabular}{|c|c|c|c|c|c|}
\hline Reference & Drug & Previous therapy & $\mathbf{n}$ & Phase & Response rate \\
\hline \multirow[t]{3}{*}{ Camidge et $\mathrm{al}^{33}$} & Crizotinib & First-line and salvage & I43 crizotinib-naive & I & $60.8 \%$ \\
\hline & & therapy & First-line therapy & & $63.6 \%$ \\
\hline & & & Salvage therapy ( $2-3$ lines) & & $58.7 \%-64.5 \%$ \\
\hline \multirow[t]{2}{*}{ Kim et $\mathrm{a}^{34}$} & Crizotinib & Salvage therapy & 803 crizotinib-naive & II & $46 \%$ \\
\hline & & & 26I "mature population"* & & $60 \%$ \\
\hline Shaw et $\mathrm{a}^{37}$ & Crizotinib & Second-line & 173 crizotinib-naive & III & $65.7 \%$ \\
\hline \multirow{3}{*}{ Shaw et al ${ }^{48}$} & LDK378 & Salvage therapy & 59 & I & $41 \%$ \\
\hline & & & Crizotinib-naive $(n=14)$ & & $21 \%$ \\
\hline & & & Crizotinib-pretreated $(n=45)$ & & $47 \%$ \\
\hline Kiura et a $\left.\right|^{50}$ & $\mathrm{CH} 5424802$ & Salvage therapy & 20 crizotinib-naive & I & $85 \%$ \\
\hline Nishio et $\mathrm{al}^{51}$ & $\mathrm{CH} 5424802$ & Salvage therapy & 45 crizotinib-naive & ॥ & $85 \%$ \\
\hline \multirow[t]{3}{*}{ Gettinger et $\mathrm{a}^{52}$} & AP26113 & Salvage therapy & II & $\mathrm{I} / \mathrm{II}$ & $73 \%$ \\
\hline & & & Crizotinib-naive $(n=2)$ & & $100 \%$ \\
\hline & & & Crizotinib-pretreated $(\mathrm{n}=9)$ & & $67 \%$ \\
\hline \multirow[t]{3}{*}{ Felip et al ${ }^{53}$} & AUY922 & Salvage therapy & 22 & ॥ & $32 \%$ \\
\hline & & & Crizotinib-naive $(n=8)$ & & $50 \%$ \\
\hline & & & Crizotinib-pretreated $(n=14)$ & & $21 \%$ \\
\hline
\end{tabular}

Notes: *The mature population concerned the first 26 I patients included and treated in the study as of February I, 20I I; salvage therapy refers to patients treated with at least one previous therapy. 


\section{Phase II study with crizotinib}

A phase II study (Profile 1005) in advanced $A L K$-positive NSCLC is ongoing. First results were presented at the 2012 American Society of Clinical Oncology (ASCO) and European Society for Medical Oncology (ESMO) meetings. ${ }^{34}$ Crizotinib $250 \mathrm{mg}$ twice daily was orally administered to patients progressing after at least one previous chemotherapy regimen. Patients with brain metastases were not excluded. As of January 2012, 901 patients had been registered, of whom 803 were assessable for response. A subgroup including a so-called mature population of 261 patients (those enrolled and treated before February 2011) was evaluated. Demographics were similar to previous epidemiological studies (Table 1) with a predominance of nonsmokers (66\%), adenocarcinoma (92\%), and good ECOG performance status of $0 / 1(82 \%)$. The median duration of treatment was 20 weeks in the whole group, but 48 weeks (range 1-94) in the mature population. Results of the previous study were confirmed either in the whole group or in the mature population, with respective RRs of $46 \%$ (95\% CI $42 \%-50 \%$ ) and $60 \%(95 \% \mathrm{CI}$ $54 \%-66 \%$ ), disease-control rates at 6/12 weeks of $80 \%(95 \%$ CI $77 \%-83 \%) / 61 \%(95 \%$ CI $58 \%-64 \%)$ and $86 \%(95 \% \mathrm{CI}$ $82 \%-90 \%$ ) $/ 75 \%$ (95\% CI 70\%-80\%), and median progressionfree survival of 8.1 months (95\% CI 6.9-9.5) and 8.1 months (95\% CI 6.8-9.7). While $15 \%$ of the patients discontinued treatment due to adverse events, these were generally of low grade, confirming the phase I data. ${ }^{33}$ They mainly consisted of visual disturbances, gastrointestinal disorders (nausea, vomiting, constipation, or diarrhea) and transaminase abnormalities.

Visual disorders are an uncommon side effect observed with other targeted therapies, such as mitogen-protein activated kinase (MEK) inhibitors, and occurred in up to $60 \%$ of the patients treated with crizotinib. ${ }^{31,35}$ They are generally mild and can reverse while on treatment. Most commonly, they present as flashing lights, streamers, or overlapping images without impact on daily living. The impact of crizotinib on quality of life (QOL) was assessed as a secondary end point in the Profile 1005 study ${ }^{36}$ It was confirmed that a clinically significant deterioration was due to constipation and diarrhea. Despite these adverse events, a significant improvement in the QOL European Organisation for Research and Treatment of Cancer QLQ-C30 questionnaire was found for global QOL, physical, role and, social functioning, and for some patients, self-reported symptoms included cough, pain, dyspnea, and fatigue.

\section{Phase III trials with crizotinib}

Two phase III trials comparing crizotinib to chemotherapy have been designed. Profile $1007^{37}$ is comparing crizotinib to docetaxel or pemetrexed in advanced $A L K$-positive NSCLC in a second-line setting. Patients presenting with $A L K$-positive NSCLC by central FISH testing progressing after one previous platinum-based chemotherapy, ECOG performance status $0-2$, and a measurable disease were eligible. Brain metastases were allowed, provided that they have been previously treated. Patients were randomized between oral crizotinib at $250 \mathrm{mg}$ twice daily or monotherapy with pemetrexed (500 $\mathrm{mg} / \mathrm{m}^{2}$ with folate and vitamin $B_{12}$ supplementation) or docetaxel $\left(75 \mathrm{mg} / \mathrm{m}^{2}\right)$ every 3 weeks. In case of progression on chemotherapy, patients were allowed to cross over on crizotinib. The primary end point was progression-free survival, assessed by an independent radiological board. One hundred seventy-three patients were randomized to crizotinib and 174 to chemotherapy, of whom 99 and 72 received pemetrexed and docetaxel, respectively. As for previous populations, there was a high proportion of nonsmokers and a large predominance of adenocarcinoma (95\%). Median progression-free survival was substantially improved from 3.0 months for the chemotherapy arm to 7.7 months in the crizotinib one (hazard ratio [HR] 0.49, 95\% CI 0.37-0.64; $P<0.0001$ ). The comparison of crizotinib with each chemotherapeutic drug also showed a significant improvement with respective median progression-free survival of $4.2(P=0.0004)$ and 2.6 months $(P<0.0001)$ for pemetrexed and docetaxel. An impressive RR in the second-line setting was observed with crizotinib (65.7\%), while it was higher, as expected, for pemetrexed $(29.3 \%)$ and in the classical range for docetaxel $(6.9 \%)$. This effectiveness did not result in prolonged survival at the first interim analysis with medians of 20.3 and 22.8 months (HR $1.02,95 \%$ CI $0.68-1.54 ; P=0.54$ ) for the crizotinib and chemotherapy arms. However, 111 patients crossed over to crizotinib after chemotherapy failure. When performing survival analysis adjusting for crossover, the HR was 0.83 (95\% CI 0.36-1.35). As expected from previous publications, the most frequent adverse event related to crizotinib administration was visual disorders of grade 1-2. Nevertheless, some important signals came from this study concerning nonhematological adverse events. These included grade 3-4 transaminase elevation in up to $16 \%$ of the cases, but also pulmonary embolism, pneumonia, hypokalemia and QTc prolongation in $4 \%$ of the patients treated with crizotinib. It must be stressed that one patient died from arrhythmia in the crizotinib group. Despite these adverse events, a statistically significant improvement in global QOL, physical, emotional, and social functioning, as well as for cough, dyspnea, fatigue, alopecia, insomnia, and pain (all $P<0.0001$ ) were noted with crizotinib, confirming the first results reported in Profile 1005. Importantly, time to deterioration in lung cancer 
symptoms was significantly longer with crizotinib than with chemotherapy, with medians of 5.6 and 1.4 months (HR 0.54, 95\% CI $0.40-0.71 ; P<0.0001)$, respectively.

A phase III randomized trial is ongoing, comparing crizotinib to a combination of cisplatin and pemetrexed in chemotherapy-naive ALK-positive NSCLC patients, with crossover allowed at progression. The primary end point is progression-free survival.

Phase I and randomized studies are not designed to answer the question of improving survival with crizotinib in comparison with conventional chemotherapy, as crossover is allowed in randomized trials. Data reporting survival improvement with crizotinib in $A L K$-positive NSCLC came from a retrospective case-control study. ${ }^{38}$ The cases consisted of the $82 \mathrm{ALK}$-positive patients included in the initial phase I study, ${ }^{24}$ and the controls were advanced NSCLC patients who had tested positive for $E M L 4-A L K$ fusion and were not receiving crizotinib ( $\mathrm{n}=36)$, with $E G F R$ mutation and negative for $A L K$ $(n=67)$, or negative for both genomic abnormalities $(n=253)$. The median survival time for crizotinib-treated patients was not reached, with 1- and 2-year survival rates of 74\% (95\% CI $63 \%-82 \%)$ and 54\% (95\% CI 40\%-66\%). When looking at comparable groups, including non-Korean patients receiving crizotinib in second- or third-line therapy $(n=30)$ and crizotinib-naive patients receiving any second-line therapy ( $n=23$ ), a survival improvement was documented, with 1and 2 -year survival rates of 70\% (95\% CI 50\%-83\%) and 55\% (95\% CI 33\%-72\%) versus 44\% (95\% CI 23\%-64\%) and $12 \%(95 \%$ CI 2\%-30\%), respectively. Median survival time was not reached for the crizotinib group, while it was 6 months (95\% CI 4-17 months) for the crizotinib-naive one. The HR for overall survival was 0.36 (95\% CI 0.17-0.75; $P=0.004)$. $A L K$-negative patients showed similar survival to crizotinib-naive $A L K$-positive ones ( $P=0.18$ ), but there was reduced prognosis in comparison with those NSCLC patients receiving crizotinib for second- or third-line therapy (HR $0.49,95 \%$ CI $0.27-0.91 ; P=0.02$ ). The incremental survival obtained with crizotinib was of the same order as the addition of an EGFR tyrosine kinase inhibitor in $E G F R$-mutated tumors $(P=0.58)$. These results suggested that $E M L 4-A L K$ is not a prognostic factor for survival but is predictive of the efficacy of the $A L K$ inhibitor crizotinib.

Based on these results, the US FDA approved in August 2011 crizotinib administration in $A L K$-positive (that needs to be detected by an FDA-approved test) locally advanced or metastatic NSCLC. In Europe, the European Medicines Agency approved in July 2012 crizotinib for the treatment of adults with previously treated $A L K$-positive advanced NSCLC.

\section{Resistance to crizotinib}

Development of resistance is observed in virtually all patients, even with very active targeted therapies as EGFR tyrosine kinase inhibitors in EGFR-mutated NSCLC or crizotinib in $A L K$-positive tumors. The first case of crizotinib-resistant tumor was reported in a young NSCLC patient presenting with a 5-month response duration to the $A L K$ inhibitor. ${ }^{39}$ Two mutations in the tyrosine kinase domain of EML4-ALK were documented - C1156Y and L1196M. Another case was subsequently published showing another mutation in the kinase domain (L1152R) with a coexisting activation of EGFR signaling. ${ }^{40}$ In vitro models suggested that different mechanisms are responsible for the resistance to crizotinib, including gene amplification and mutations in the gatekeeper kinase domain that can be overridden by other $A L K$ inhibitors, such as TAE684, or Hsp90 inhibitors. ${ }^{41}$ These observations were recently confirmed in two series of NSCLC patients progressing on crizotinib. In the first one, ${ }^{42}$ a secondary mutation in the $A L K$ tyrosine kinase domain or a gene amplification was found in $28 \%$ of the cases. Aberrant mutations including KIT and increased EGFR autophosphorylation were also documented, while multiple mechanisms were coexisting. In the second series, ${ }^{43}$ secondary mutations in the $A L K$ tyrosine kinase domain, $A L K$ copy number gain, and the presence of another oncogene driver (EGFR or KRAS) were responsible for the resistance to crizotinib. The same author reported during the 2012 ASCO meeting a series of 16 patients progressing on crizotinib with the same distribution of genomic alterations. He suggested a separation of resistant tumors into those having persistent $A L K$ dominance (secondary mutations in the $A L K$ tyrosine kinase domain with or without increased gene copy number) from those that are $A L K$ nondominant (other oncogene driver, loss of the $A L K$ translocation). ${ }^{44}$

\section{New strategies for $A L K$ inhibition}

Further $A L K$ or Hsp90 inhibitors are currently in development at a preclinical or a clinical stage, most of them having dual or multiple therapeutic targets or demonstrating activity in crizotinib-resistant $A L K$-positive NSCLC strains. The main compounds are developed by Novartis (NVP-TAE684, LDK378, 3-39, AUY922 [Hsp90 inhibitor]), Chugai (CH5424802), Astrella (ASP3026), Ariad (AP26113), GlaxoSmithKline (GSK 1838705A), Xcovery (X-396), Infinity (IPI504, an Hsp90 inhibitor), Nerviano Medical Science (NMS-E628), and Cephalon (CEP-14083, CEP-28122). ${ }^{9,45-47}$ Few clinical data are currently available.

Some early phase I or II studies, all performed in pretreated patients, were presented at the 2012 ASCO and 
ESMO meetings. In a dose-escalating phase I study including $A L K$-positive solid tumors of any type, LDK378 was administered to 79 NSCLC patients, of whom 56 were pretreated with crizotinib. ${ }^{48}$ LDK378 is active on conventional $A L K-$ positive tumors but also on those expressing the gatekeeper mutation $\mathrm{C} 1156 \mathrm{Y}$ and the insulin growth factor 1 receptor. Among 59 patients receiving an LDK378 dose between 400 and $750 \mathrm{mg}$ per day, an objective response was documented in 24 cases $(41 \%)$ and in 21 patients progressing after crizotinib (47\%). Activity was also found on brain metastases. Phase II studies are planned either in $A L K$-positive NSCLC pretreated with chemotherapy and crizotinib and in those naive of $A L K$ inhibitor. CH5424802 is presenting with different binding capacity to the adenosine triphosphate pocket of the $A L K$ domain, explaining better inhibition of $A L K$-positive tumors less sensitive to crizotinib and activity in the presence of the gatekeeper mutation of the $A L K$ domain, L1196M, and $\mathrm{C} 1156 \mathrm{Y}$, with tenfold more potency than crizotinib. ${ }^{49}$ This compound was tested in a phase I/II study in previously treated $A L K$-positive NSCLC patients naive to crizotinib. In the phase I part, an $85 \%$ response rate was observed among 20 assessable patients. ${ }^{50}$ Preliminary results of the phase II confirmed an RR of 85\% (95\% CI 71\%-94\%) among 45 evaluable patients, including regression of brain metastases. ${ }^{51}$ AP26113, which is potentially active both on $A L K$-positive and $E G F R$-mutated tumors, including the T790M mutation, showed activity in crizotinib-resistant $A L K$-positive NSCLC in a dose-finding phase I/II study ${ }^{52}$ AP26113 is, in vitro, ten times more powerful for $A L K$ and $R O S 1$ inhibition than crizotinib and is also active in the case of L1196M mutation in a model of acquired resistance to crizotinib. ${ }^{41}$ Among eleven

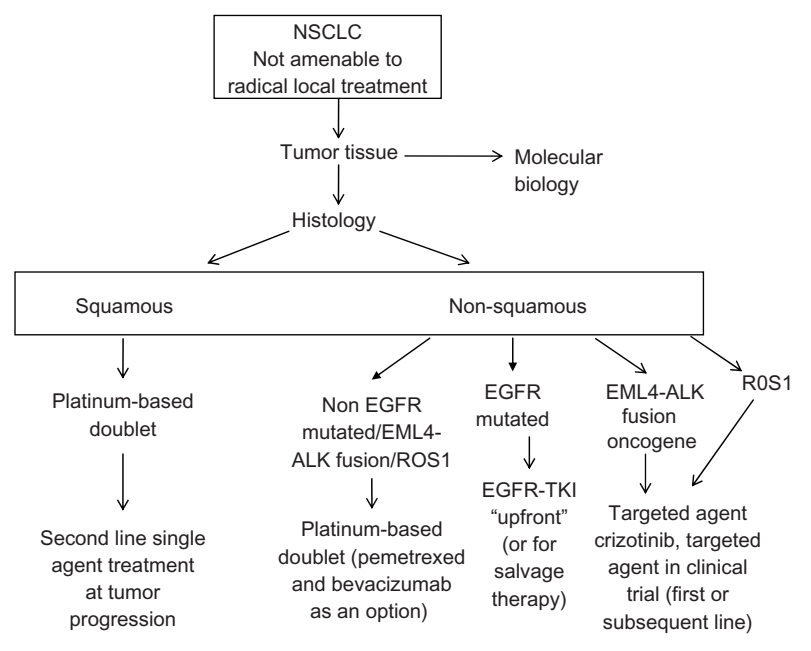

Figure 2 Proposed algorithm for the therapeutic management of advanced or metastatic NSCLC not amenable to radical local treatment. assessable patients with $A L K$-positive NSCLC, eight partial responses were noted, of which six occurred in nine patients progressing on crizotinib. The drug appears to be active on brain metastases. Lastly, AUY922, an Hsp90 inhibitor, was tested in a phase II study including $A L K$-positive and $E G F R$ mutated NSCLC. ${ }^{53}$ Among 22 assessable $A L K$-positive tumors, seven objective responses (32\%) were noted, three among 14 crizotinib-resistant NSCLC patients. The disease-control rate for the whole group was 59\%, being $100 \%$ and $36 \%$ in the crizotinib-naive and -resistant groups respectively. All these preliminary data (Table 2) support the use of $A L K$ and Hsp90 inhibitors in NSCLC patients presenting with $E M L 4-A L K$ gene fusion, whether sensitive or resistant to crizotinib.

Crizotinib has other potential promise for advanced NSCLC. It has shown clinical activity in another subgroup of NSCLC patients harboring ROS1 rearrangement. In an expansion cohort of the initial phase I study, 23 patients, of whom 20 were assessable for response, were included. A $50 \%$ objective response rate was noted, and recruitment is ongoing. ${ }^{54}$ This drug is also currently tested in combination as a way to overcome acquired resistance to EGFR tyrosine kinase inhibitors. ${ }^{55,56}$

\section{Conclusion}

Knowledge of cancer biology and oncogenic drivers has led to a better understanding of lung cancer and the development of very active targeted therapies. Nowadays, EGFR tyrosine kinase inhibitors for tumors presenting with an activating mutation are the standard of care in NSCLC. New targets have been identified, including the EML4-ALK gene fusion, which is a relatively rare genetic abnormality predominant in adenocarcinomas. Crizotinib, a dual $A L K$ and $c M E T$ inhibitor, showed impressive activity in this small group of patients when given as first-line or salvage therapy, whatever the number of previous chemotherapy lines. Based on available data, Figure 2 is a proposed algorithm for the therapeutic management of NSCLC. As observed with other targeted agents, resistance occurs invariably. Research has identified secondary $A L K$ mutations, gene amplification, and other aberrant mutations (KIT, EGFR, KRAS, etc) as the main mechanisms. New $A L K$ and Hsp90 inhibitors are under clinical investigation and have shown promising results in early phase I/II studies.

\section{Disclosure}

The authors have no conflicts of interest to be declared in relationship with the present manuscript. 


\section{References}

1. Goldstraw P, Crowley J, Chansky K, et al. The IASLC Lung Cancer Staging Project: proposals for the revision of the TNM stage groupings in the forthcoming (seventh) edition of the TNM Classification of malignant tumors. J Thorac Oncol. 2007;2(8):706-714.

2. NSCLC Meta-Analyses Collaborative Group. Chemotherapy in addition to supportive care improves survival in advanced non-small-cell lung cancer: a systematic review and meta-analysis of individual patient data from 16 randomized controlled trials. J Clin Oncol. 2008;26(28):4617-4625.

3. Sculier JP, Moro-Sibilot D. First- and second-line therapy for advanced nonsmall cell lung cancer. Eur Respir J. 2009;33(4):915-930.

4. Treat J, Scagliotti GV, Peng G, Monberg MJ, Obasaju CK, Socinski MA. Comparison of pemetrexed plus cisplatin with other first-line doublets in advanced non-small cell lung cancer (NSCLC): a combined analysis of three phase 3 trials. Lung Cancer. 2012;76(2):222-227.

5. Heist RS, Sequist LV, Engelman JA. Genetic changes in squamous cell lung cancer: a review. J Thorac Oncol. 2012;7(5):924-933.

6. Sasaki T, Rodig SJ, Chirieac LR, Janne PA. The biology and treatment of EML4-ALK non-small cell lung cancer. Eur J Cancer. 2010;46(10): 1773-1780.

7. Kelleher FC, McDermott R. The emerging pathogenic and therapeutic importance of the anaplastic lymphoma kinase gene. Eur J Cancer. 2010;46(13):2357-2368.

8. Soda M, Choi YL, Enomoto M, et al. Identification of the transforming EML4-ALK fusion gene in non-small-cell lung cancer. Nature. 2007;448(7153):561-566.

9. Grande E, Bolos MV, Arriola E. Targeting oncogenic ALK: a promising strategy for cancer treatment. Mol Cancer Ther. 2011;10(4):569-579.

10. Rikova K, Guo A, Zeng Q, et al. Global survey of phosphotyrosine signaling identifies oncogenic kinases in lung cancer. Cell. 2007; 131(6):1190-1203.

11. Takeuchi K, ChoiYL, TogashiY, et al. KIF5B-ALK, a novel fusion oncokinase identified by an immunohistochemistry-based diagnostic system for ALK-positive lung cancer. Clin Cancer Res. 2009;15(9):3143-3149.

12. Thunnissen E, Bubendorf L, Dietel M, et al. EML4-ALK testing in non-small cell carcinomas of the lung: a review with recommendations. Virchows Arch. 2012;461(3):245-257.

13. Wallander ML, Geiersbach KB, Tripp SR, Layfield LJ. Comparison of reverse transcription-polymerase chain reaction, immunohistochemistry, and fluorescence in situ hybridization methodologies for detection of echinoderm microtubule-associated proteinlike 4-anaplastic lymphoma kinase fusion-positive non-small cell lung carcinoma: implications for optimal clinical testing. Arch Pathol Lab Med. 2012;136(7): 796-803.

14. Jokoji R, Yamasaki T, Minami S, et al. Combination of morphological feature analysis and immunohistochemistry is useful for screening of EML4-ALK-positive lung adenocarcinoma. J Clin Pathol. 2010; 63(12):1066-1070.

15. Inamura $\mathrm{K}$, Takeuchi $\mathrm{K}$, Togashi $\mathrm{Y}$, et al. EML4-ALK fusion is linked to histological characteristics in a subset of lung cancers. J Thorac Oncol. 2008;3(1):13-17.

16. Inamura $\mathrm{K}$, Takeuchi $\mathrm{K}$, Togashi $\mathrm{Y}$, et al. EML4-ALK lung cancers are characterized by rare other mutations, a TTF-1 cell lineage, an acinar histology, and young onset. Mod Pathol. 2009;22(4):508-515.

17. Koivunen JP, Mermel C, Zejnullahu K, et al. EML4-ALK fusion gene and efficacy of an ALK kinase inhibitor in lung cancer. Clin Cancer Res. 2008;14(13):4275-4283.

18. Shaw AT, Yeap BY, Mino-Kenudson M, et al. Clinical features and outcome of patients with non-small-cell lung cancer who harbor EML4ALK. J Clin Oncol. 2009;27(26):4247-4253.

19. Sun Y, Ren Y, Fang Z, et al. Lung adenocarcinoma from East Asian never-smokers is a disease largely defined by targetable oncogenic mutant kinases. J Clin Oncol. 2010;28(30):4616-4620.

20. Takahashi T, Sonobe M, Kobayashi M, et al. Clinicopathologic features of non-small-cell lung cancer with EML4-ALK fusion gene. Ann Surg Oncol. 2010;17(3):889-897.
21. Wong DW, Leung EL, So KK, et al. The EML4-ALK fusion gene is involved in various histologic types of lung cancers from nonsmokers with wild-type EGFR and KRAS. Cancer. 2009;115(8):1723-1733.

22. Zhang X, Zhang S, Yang X, et al. Fusion of EML4 and ALK is associated with development of lung adenocarcinomas lacking EGFR and KRAS mutations and is correlated with ALK expression. Mol Cancer. 2010;9:188.

23. Rosell R, Massuti Sureda B, Costa C, et al. Concomitant actionable mutations and overall survival in EGFR-mutant NSCLC pts included in EURTAC trial: EGFR L858R, EGFR T790M, TP53, R273H and EML4-ALK. Ann Oncol. 2012;23 Suppl 9:31.

24. Kwak EL, Bang YJ, Camidge DR, et al. Anaplastic lymphoma kinase inhibition in non-small-cell lung cancer. N Engl J Med. 2010; 363(18):1693-1703.

25. Leer-Florin A, Lantuejoul S. Why technical aspects rather than biology explain cellular heterogeneity in ALK-positive non-small cell lung cancer. J Thorac Dis. 2012;4(3):240-241.

26. Murakami Y, Mitsudomi T, Yatabe Y. A screening method for the ALK fusion gene in NSCLC. Front Oncol. 2012;2:24.

27. Mino-Kenudson M, Chirieac LR, Law K, et al. A novel, highly sensitive antibody allows for the routine detection of ALK-rearranged lung adenocarcinomas by standard immunohistochemistry. Clin Cancer Res. 2010; 16(5):1561-1571.

28. Just PA, Cazes A, Audebourg A, et al. Histologic subtypes, immunohistochemistry, FISH or molecular screening for the accurate diagnosis of ALK-rearrangement in lung cancer: a comprehensive study of Caucasian non-smokers. Lung Cancer. 2012;76(3):309-315.

29. Martelli MP, Sozzi G, Hernandez L, et al. EML4-ALK rearrangement in non-small cell lung cancer and non-tumor lung tissues. Am J Pathol. 2009;174(2):661-670.

30. Blackhall FH, Peters S, Kerr K, et al. Prevalence and clinical outcomes for patients with ALK gene rearrangement in Europe: preliminary results from the European Thoracic Oncology Platform Lungscape project. Ann Oncol. 2012;23 Supp1 9:ix73-ix94.

31. Curran MP. Crizotinib: in locally advanced or metastatic non-small cell lung cancer. Drugs. 2012;72(1):99-107.

32. Kwak EL, Camidge DR, Clark JW, et al. Clinical activity observed in a phase I dose escalation trial of an oral c-MET and ALK inhibitor, PF-02341066. J Clin Oncol. 2009;27(Suppl 15):3509.

33. Camidge DR, Bang YJ, Kwak EL, et al. Activity and safety of crizotinib in patients with ALK-positive non-small-cell lung cancer: updated results from a phase 1study. Lancet Oncol. 2012;13(10): 1011-1019.

34. Kim DW, Ahn MJ, Yang PC, et al. Updated results of a global phase II study with crizotinib in advanced ALK-positive non-small cell lung cancer (NSCLC). Ann Oncol. 2012;23 Suppl 9:ix400-ix446.

35. Salgia R, Solomon B, Shaw AT, et al. Visual effects in anaplastic lymphoma kinase (ALK)-positive advanced non-small cell lung cancer (NSCLC) patients treated with crizotinib. J Clin Oncol. 2012; 30 Suppl:7596.

36. Blackhall FH, Evans TL, Han J, et al. Impact of crizotinib treatment on patient-reported symptoms and quality of life (QOL) in advanced ALK-positive non-small cell lung cancer (NSCLC). Ann Oncol. 2012; 23 Suppl 9:ix400-ix446.

37. Shaw AT, Kim D, Nakagawa K, et al. Phase III study of crizotinib vs pemetrexed or docetaxel chemotherapy in patients with advanced $A L K$ positive NSCLC. Ann Oncol. 2012;23 Suppl 9:LBA1.

38. Shaw AT, Yeap BY, Solomon BJ, et al. Effect of crizotinib on overall survival in patients with advanced non-small-cell lung cancer harbouring ALK gene rearrangement: a retrospective analysis. Lancet Oncol. 2011;12(11):1004-1012.

39. Choi YL, Soda M, Yamashita Y, et al. EML4-ALK mutations in lung cancer that confer resistance to ALK inhibitors. $N$ Engl J Med. 2010;363(18):1734-1739.

40. Sasaki T, Koivunen J, Ogino A, et al. A novel ALK secondary mutation and EGFR signaling cause resistance to ALK kinase inhibitors. Cancer Res. 2011;71(18):6051-6060. 
41. Katayama R, Khan TM, Benes C, et al. Therapeutic strategies to overcome crizotinib resistance in non-small cell lung cancers harboring the fusion oncogene EML4-ALK. Proc Natl Acad Sci US A. 2011;108(18):7535-7540.

42. Katayama R, Shaw AT, Khan TM, et al. Mechanisms of acquired crizotinib resistance in ALK-rearranged lung cancers. Sci Transl Med. 2012;4(120):120ra17.

43. Doebele RC, Pilling AB, Aisner DL, et al. Mechanisms of resistance to crizotinib in patients with ALK gene rearranged non-small cell lung cancer. Clin Cancer Res. 2012;18(5):1472-1482.

44. Doebele RC, Aisner DL, Le AT, et al. Analysis of resistance mechanisms to ALK kinase inhibitors in ALK+NSCLC patients. J Clin Oncol. 2012;30 Suppl:7504.

45. Cheng M, Quail MR, Gingrich DE, et al. CEP-28122, a highly potent and selective orally active inhibitor of anaplastic lymphoma kinase with antitumor activity in experimental models of human cancers. $\mathrm{Mol}$ Cancer Ther. 2012;11(3):670-679.

46. Hallberg B, Palmer RH. ALK and NSCLC: targeted therapy with ALK inhibitors. F1000 Med Rep. 2011;3:21.

47. Kinoshita K, Asoh K, Furuichi N, et al. Design and synthesis of a highly selective, orally active and potent anaplastic lymphoma kinase inhibitor (CH5424802). Bioorg Med Chem. 2012;20(3):1271-1280.

48. Shaw AT, Camidge DR, Felip E, et al. Results of a first-in-human phase I study of the ALK inhibitor LDK378 in advanced solid tumors [abstract 440]. Ann Oncol. 2012;23 Suppl 9:ix152-ix174.

49. Sakamoto H, Tsukaguchi T, Hiroshima S, et al. CH5424802, a selective ALK inhibitor capable of blocking the resistant gatekeeper mutant. Cancer Cell. 2011;19(5):679-690.

50. Kiura K, Seto T, Yamamoto N, Nishio M, Nakagawa K, Tamura T. A first-in-human phase I/II study of ALK inhibitor CH5424802 in patients with ALK-positive NSCLC. J Clin Oncol. 2012;30 Suppl:7602.
51. Nishio M, Kiura K, Nakagawa K, et al. A phase I/II study of ALK inhibitor CH5424802 in patients with ALK-positive NSCLC; safety and efficacy interim results of the phase II portion [abstract 439]. Ann Oncol. 2012. 23 Suppl 9:ix152-ix174.

52. Gettinger S, Weiss GJ, Salgia R, et al. A first-in-human dose-finding study of the ALK/EGFR inhibitor AP26113 in patients with advanced malignancies. Ann Oncol. 2012;23 Suppl 9:ix152-ix174.

53. Felip E, Carcereny E, Barlesi F, et al. Phase II activity of the Hsp90 inhibitor AUY922 in patients with ALK-rearranged (ALK+) or EGFR-mutated advanced non-small cell lung cancer (NSCLC) [abstract 438]. Ann Oncol. 2012;23 Suppl 9:ix152-ix174.

54. Ou SI, Camidge DR, Engelman JA, et al. Clinical activity of crizotinib in patients with advanced non-small cell lung cancer (NSCLC) harboring ROS1 gene rearrangement. Ann Oncol. 2012;23 Suppl 9: ix389-ix399.

55. Janne PA, Shaw AT, Giaccone G, et al. Phase I trial of irreversible panerbb inhibitor dacomitinib (DAC) in combination with alk/met inhibitor crizotinib (CRIZ) in previously treated advanced non-small cell lung cancer (NSCLC). Ann Oncol. 2012;23 Suppl 9:ix152-ix174.

56. Ou SI, Govindan R, Eaton K, et al. Phase I/II dose-finding study of crizotinib (CRIZ) in combination with erlotinib (E) in patients (pts) with advanced non-small cell lung cancer (NSCLC). Ann Oncol. 2012; 23 Suppl 9:ix400-ix446.

57. Perner S, Wagner PL, Demichelis F, et al. EML4-ALK fusion lung cancer: a rare acquired event. Neoplasia. 2008;10(3):298-302.

58. Perner S, Wilbertz T, Stiedl AC, Rubin MA . EML4 (echinoderm microtubule associated protein like 4). Atlas Genet Cytogenet Oncol Haematol. July 2009. Webpage on the internet available at http://atlasgeneticsoncology.org/Genes/EML4ID44353ch2p21.html. Poitiers, France: University Hospital.
Lung Cancer: Targets and Therapy

\section{Publish your work in this journal}

Lung Cancer: Targets and Therapy is an international, peer-reviewed, open access journal focusing on lung cancer research, identification of therapeutic targets and the optimal use of preventative and integrated treatment interventions to achieve improved outcomes, enhanced survival and quality of life for the cancer patient. Specific topics covered in the journalinclude: Epidemiology, dete Cellular research and biomarkers; Identification of biotargets and agents with nove

\section{Dovepress}

mechanisms of action; Optimal clinical use of existing anticancer agents, including combination therapies; Radiation and surgery; Palliative care; Patient adherence, quality of life, satisfaction; Health economic evaluations. The manuscript management system is completely online and includes a very quick and fair peer-review system. Visit http://www.dovepress.com/testimonials.php to read real quotes from published authors. 